\title{
SCIENTOLOGY - ET BARN AF MODERNITETEN?
}

En anmærkning til brugen af

Webers rationaliseringsbegreb i forbindelse med Scientology

Ulrik Houlind Rasmussen

\author{
Wissenschaft ... entsteht, \\ ... wenn die Götter nicht \\ gut gedacht werden. \\ Friedrich Nietzsche
}

\begin{abstract}
ENGLISH ABSTRACT: Weber's famous and ambivalent analysis of the rationalization of modernity often leads to interpretations of New Religious Movements (NRMS) as particularly accommodated to modern, rationalized societies. The author discusses existing efforts to understand Scientology as a specific modern religion (Locke, Wallis, Whitehead, Wilson) and argues that apparent 'contradictions' in Weber's rationalization thesis are due to simplifications, which do not appreciate the dialectical 'ambiguity' in his work, where modernity is characterized by rationalization and disenchantment, as well as by irrationalization and reenchantment. The interpretation of the School of Joachim Ritter in terms of 'compensation' or a 'positive split' enables an understanding of NRMS as exact manifestations of what Weber considered to be fundamental to the modern world.
\end{abstract}

DANSK RESUME: I forlengelse af Webers berømte og ambivalente analyse af modernitetens rationalisering anses nye religiøse bevcegelser ofte for scrligt veltilpassede til moderne, rationaliserede samfund. Forfatteren diskuterer eksisterende forsøg på at forstå Scientology som en specifik moderne religion (Locke, Wallis, Whitehead, Wilson) og argumenterer for, at tilsyneladende modsctninger $i$ Webers tese i virkeligheden skyldes simplificeringer, hvor den dialektiske forståelse af moderniteten som karakteriseret af rationalisering og affortryllelse såvel som irrationalisering og genfortryllelse overses. Den såkaldte Joachim Ritterskoles fortolkning vha. begrebet 'kompensation' eller en 'positiv splittelse' muliggør forståelsen af nye religiøse bevcegelser som klare manifestationer af netop det, som Weber anså for fundamentalt for den moderne verden.

KEYWORDS: Max Weber; Scientology; rationalization; modernization; new religious movements; Joachim Ritter.

\section{Indledning}

Det er øjensynligt blevet moderne at tale om det moderne og dét til trods for, at det moderne ret beset er noget temmelig gammelt. Forsøgene på at give periodebetegnelsen moderne en entydig definition har imidlertid været så mange, at entydighed for længst 
er blevet et videnskabsteoretisk fatamorgana. Der findes nu engang ikke noget perspektivløst 'Hochsitzt', hvorfra moderniteten kan overskues og fastlægges i urokkelig entydighed. Hvad det moderne er, beror i bemærkelsesværdig grad på en fortolkning, der medkonstituerer selve bestemmelsen. Når jeg i det følgende skal undersøge, hvorvidt Scientology lader sig forstå som et svar på det, der her vil blive behandlet under overskriften 'modernitetens rationalisering', er der derfor også først og fremmest tale om et fortolkningsudkast, der selvsagt ikke foregiver at være det sidste ord om sagen Scientology og det moderne. Velkommen til en religionsteoretisk enmandsekspedition ud i modernitetstemaets vildnis!

Artiklens grundintention er at undersøge, hvorvidt Scientology kan betragtes som særligt kendetegnende for de rationaliseringsprocesser, som ikke mindst Max Weber (1864-1920) har fremhævet som karakteristiske for modernitetens tilblivelse. Webers modernitetsteoretiske overvejelser vil således udgøre den hovedakse, omkring hvilken bestemmelsen af det moderne vil centrere sig, idet Webers modernitetskarakteristik stadig besidder en betydelig religionsteoretisk relevans for forståelsen af det moderne.

Når Scientology i det følgende omtales som 'et barn af moderniteten', skal dette selvsagt ikke udelukkende forstås som det trivielle forhold, at Scientology - modeleret over Lafayette Ron Hubbards (1911-1986) tanker og belæringer - fødtes i den tidsalder, man bl.a. har kaldt moderniteten, og som dermed per definition må høre moderniteten til. Karakteristikken henviser derimod til, at Scientologys undfangelse og succes må anskues som en konkret replik på en række modernitetsbetingede grundvilkår, dvs. forstås som et mere eller mindre direkte udtryk for de sociokulturelle jordskred, som moderniteten ifølge Weber har indvarslet.

Hvad angår fremstillingen af Scientology, er det klart, at den må bære præg af visse forbehold. Indfaldsvinklerne til Scientology er selvsagt mangfoldige, og chancerne for at få en enkelt, fundamental orienteringsmodel i hænderne, er ikke mere iøjnefaldende her end på et hvilket som helst andet religionsteoretisk område. Scientology er klart nok tilgængelig i form af et efterhånden ganske voluminøst tekstmateriale. Perspektiverne i dette tekstmateriale eksisterer imidlertid ikke i sig selv, men er kun tilgængelig gennem et fortolkningsarbejde, som nødvendigvis må stå i kritisk dialog med andre fortolkninger og udlægninger. Og hermed til sagen.

\section{Webers modernitetstese: to grundmotiver}

Randall Collins har betegnet Webers sociologiske arbejde som 'skizofrent', idet han har gjort gældende, at man i hans "bindstærke arbejder kan ... finde næsten alt det, man søger efter" (Collins 2000, 9). Trods dette angiveligt skizofrene præg i forfatterskabet kan der lokaliseres to grundmotiver i Webers sociologiske tænkning, som med rimelighed kan hævdes at udgøre den teoretiske rygrad $\mathrm{i}$ hans moderniseringsforståelse. De to grundtendenser, som den moderne, vestlige civilisation ifølge Weber er karakteriseret ved, kan sammenfattes i følgende to overskrifter: a) modernisering som kulturel affortryllelse og b) modernisering som anonymisering. 
a) Modernisering som kulturel affortryllelse

Webers forestilling om, at den moderne, vestlige verden grundlæggende er præget af en stadig rationaliserende affortryllelse ('Entzauberung'), indtager en fremskudt position ikke blot i dennes eget forfatterskab, men tillige i megen senere religionssociologisk forskning. Allermest karakteristisk og fuldstændig uadskillelig fra personen Max Weber står imidlertid dennes tese om, at det var særligt puritanske udformninger af protestantismen (i særdeleshed den calvinske prædestinationslære), der lagde grunden for den vestlige kapitalisme og ikke, som Karl Marx havde gjort gældende, kapitalismen der forårsagede religionen. Sandhedsværdien af Webers unægteligt noget kontroversielle forklaring på "die Entstehung ... der spezifisch moderne okzidentale Kapitalismus ..." (Weber 1988a, 10) skal imidlertid ikke stå til debat i nærværende artikel. Det følgende forsøg på at karakterisere Webers kulturelle moderniseringstese vil derimod tage sit udgangspunkt i, hvad Weber betragtede som et uomgængeligt træk ved den moderne, vestlige kultur, og koncentrere sig om de angivelige konsekvenser heraf.

Weber havde hele sit videnskabelige liv igennem været optaget af det 'universalhistoriske problem' om hvorfor

... außerhalb Europas weder die wissenschaftliche, noch die künstlerische, noch die staatliche, noch die wirtschaftliche Entwicklung in diejenigen Bahnen der Rationalisierung einlenken, welche dem Okzident eigen sind (Weber 1988a, 11).

Ifølge Weber er det et grundtræk ved den vestlige civilisation, at den er behersket af en helt særegen rationaliseringsform. Weber knytter imidlertid særligt den vestlige verdens kulturelle rationalisering til opblomstringen af moderne, eksakt videnskab og teknik. Således ser han den moderne videnskab, der bl.a. er karakteriseret ved en metodisk objektivering af naturen og gennemgribende matematisk-abstrakte teoridannelser, som væsensforskellig fra fx den indiske og kinesiske medicin, den babylonske og ægyptiske astronomi, ligesom det tilsvarende gælder, at "eine rationale Chemie fehlt allen Kulturgebieten außer dem Okzident” (Weber 1988a, 3). Det, som adskiller den vestlige civilisation fra verdens øvrige civilisationer, er netop dens videnskabers basale "mathematische Fundamentierung" (Weber 1988a, 4).

Ifølge Weber fremviser den moderne, vestlige civilisation således helt særegne træk, der har åbenlyse forbindelseslinjer til en særlig type rationalitet, der har tegnet sig som eksemplarisk for det Europa, hvor sekularisering, renæssance og reformation havde holdt sit afgørende indtog i 1500-tallet. Med betegnelsen 'rationel' hører Weber således tillige et ekko af den affortryllelsesproces, der i Europa førte til det religiøse og magiskes tilbagegang, og som i sidste instans angiveligt skulle indebære en verdsliggørelse af alle kulturlivets områder.

Året inden sin død i 1920 holdt Weber et foredrag i München med titlen Wissenschaft als Beruf. Denne tale, der straks blev offentliggjort, anstiller en illusionsløs samtidsdiagnose: Hvad der umiddelbart præsenteres som overvejelser omkring videnskabens moralske indstilling, videnskabens etos, rummer under overfladen et dybt indtryksfuldt portræt af den modernitet, der havde gjort videnskab og rationalisering til 
sin egen skæbne. Resultatet heraf er et grundlæggende værdi- og betydningssammenbrud, og Weber spørger...

Was ist ... der Sinn der Wissenschaft als Beruf, da alle diese früheren Illusionen: "Weg zum wahren Sein", "Weg zur wahren Kunst", "Weg zur wahren Natur", "Weg zum wahren Gott", "Weg zur wahren Glück", versunken sind? Die einfachste Antwort hat Tolstoj gegeben mit den Worten: "Sie ist sinnlos, weil sie auf die allein für uns wichtige Frage: 'Was sollen wir tun? Wie sollen wir leben?' keine Antwort gibt (Weber 1988b, 598).

Hvad Weber her gør status over er den videnskabelige fornufts begrænsning. Videnskaben kan efterprøve givne midlers egnethed til bestemte formål, den kan kortlægge og ud i detaljen beskrive hvorledes den 'ydre' verden hænger sammen, den kan - og har -i sine tekniske virkninger forandret menneskets hverdag fra grunden. Men - og det er Webers hovedindsigelse mod sin samtids drømmende fantaster, for hvem 'den nye tid' betød paradis på jord, i form af et af fornuften indrettet Utopia - videnskaben kan ikke fortælle mennesket, hvordan det skal leve og indrette sit liv. Menneskets eksistentielle spørgsmål og livsproblemer lader de moderne, eksakte videnskaber således aldeles ubesvaret. Men ikke blot det. Den videnskabelige rationalisering har tillige gjort verden til en verden af tingsliggjort geometri og meningstom nødvendighed, hvor der er plads til alle ting - blot ikke mennesket. Den betydningsskabende ramme, der holdt virkeligheden sammen for middelalderens og antikkens menneske, er kort sagt borttæret som følge af den gennemgribende affortryllelse, som det videnskabelige fremskridt ubønhørligt har ført med sig.

Weber replicerer her indirekte på det oplysningsprojekt, som var kørt i sikker stilling i det 18. århundrede. Her var oplysning frem for alt ensbetydende med fornuftens kamp mod nedarvede religiøse dogmer og tom, metafysisk spekulation. Når imidlertid al tradition, religion og kulturel fylde forsvinder (hvad Habermas samler under betegnelsen "der Naturwüchsigkeit traditionaler Lebensformen" (Habermas 1989, 104)), deporteres hermed også samtidig svaret på spørgsmålet om, hvad mennesket skal gøre, og hvorledes det skal leve sit liv. Det grundlæggende betydningstab, som Weber i det omtalte foredrag giver et signalement af, forstår han som et udslag af, at en særlig type rationalitet - den instrumentelle målrationalitet ('Zweckrationalität') - er blevet enerådende i moderniteten. Det rationelle angår nu måden, hvorpå noget opnås; om vejen til et på forhånd defineret mål gennemføres ‘økonomisk' og efter anvendelse af det til opgaven mest velegnede middel. Den målrationelle virkelighedsforståelse fortrænger således den værdirationelle, hvilket betyder, at metafysik, myte og religion gradvis afvikles som troværdige orienteringsinstanser. Denne idéhistoriske proces ville ifølge Weber i sidste instans uafværgeligt føre den endegyldige affortryllelse af religionen med sig.

Umiddelbart kunne det altså se ud, som om Weber indskriver sine synspunkter i en traditionel, kulturkritisk sekulariseringstese, hvis kendetegn, formelagtigt udtrykt, er en rationalitets- og videnskabstilvækst og en hermed korreleret depotensering af religiøse 
og metafysiske orienteringsmuligheder: Moderniseringens fremmarch er grundlæggende uforenelig med en religiøs tilværelsesfortolkning.

Webers syn på moderniseringen er imidlertid mere kompliceret end som så. Weber er opmærksom på, at rationalisering ikke blot er et uhyre perspektivrigt begreb, der unddrager sig definitorisk entydighed, men tillige et begreb, der "eine Welt von Gegensätzen in sich schließt" (Weber 1988c, 62). Rationalisering er således ifølge Weber grundlæggende en paradoksal og ambivalent proces, idet den skitserede tilvækst i videnskabelig målrationalitet samtidig involverer en komplementær modproces, der fører en modrationalitet med sig. Den øgede rationalisering ledsages kort sagt af en for moderniteten konstitutiv komplementær antirationalitet, et fænomen, der med Helmuth Spinner kan beskrives som Webers opdagelse af "die Doppeltvernunft der Moderne" (Spinner 1989, 257). En sådan modernitetens dobbeltfornuft indebærer, som vi skal se nedenfor, muligheden for artikulationen af en teori om det moderne, der kan begribe enheden af videnskabelig affortryllelse og religiøs genfortryllelse.

b) Modernisering som anonymisering

Foruden de anførte kulturhistoriske træk rummer Webers fiksering af moderniseringen også - og måske i særdeleshed - overvejelser omkring opblomstringen af særlige typer af samfund og den dermed forbundne uddifferentiering ('Ausdifferenzierung'). De to 'perspektiver' hører imidlertid sammen: De kulturelle og åndelige jordskælv, som Weber baserede sine sociologiske studier på, er samtidig mulighedsbetingelsen for den omsiggribende 'Vergesellschaftung', der leder til en anonymisering af de sociale forbindelser. I Wirtschaft und Gesellschaft (der første gang udkom i 1922) gør Weber således gældende, at bureaukratiets fremtrængen hænger intimt sammen med kapitalismens vækst.

Den tilvækst i bureaukrati og rationel-juridiske praksisformer, som kendetegner den moderne samfundsform, afføder stærkt upersonlige regler og restriktioner, der spærrer mennesket inde i bureaukratiets jernbur. De rutineprægede, monotone procedurer, der karakteriserer det moderne samfund, og de eksakte økonomiske kalkulationer, i staten udtrykt ved det formelle, kodificerede retssystem, klemmer mennesket fast i anonym identitetsløshed. Mennesket bliver til en "rational arbeitenden Maschine" (Weber 1976, 278). Ifølge Habermas er denne tingsliggørelse af de sociale bånd i særdeleshed afstedkommet af, at de forskellige organisationer vinder autonomi gennem "eine neutralisierende Abgrenzung gegen die symbolischen Strukturen der Lebenswelt" (Habermas 1981, 484), hvormed de i stigende grad forholder sig indifferente til kulturen, samfundet og enkeltindividet. Habermas sammenfatter Webers modernitetsdiagnose i to konsekvenser, idet han gør gældende, at rationaliseringstilvæksten implicerer dels et frihedstab, dels et meningstab. Samfundsmæssigt betragtet implicerer rationaliseringstilvæksten således en 'mekanisering' af de sociale forbindelser, hvorved enkeltindividet står i fare for at forsvinde sporløst ind i rationaliseringens anonymitet: Når livet domineres af regler, reguleringer og imperativer, når mennesket i stadig stigende grad kontrolleres og begrænses som udslag af rationalisering, teknificering og bureaukrati- 
sering, bliver afpersonalisering en stadig større trussel mod menneskets grundlæggende identitetsbehov.

Den menneskelige identitet risikerer med andre ord at smelte ansigtsløst sammen med dens arbejdsfunktioner. Denne tilvækst af rationel beregningsvilje har således en ildevarslende bagside, idet den afstedkommer "eine fortschreitende 'Veruntpersönlichung"' (Weber 1976, 561) af de sociale bånd og efterlader mennesket i bureaukratisk fremmedgørelse. I de moderne samfundsformer skydes det individuelle i baggrunden til fordel for en formaliseret og traditionsneutral vurdering af individet. Man er sine papirer, sine (formelt tilvejebragte) kvalifikationer og altså ikke (længere) sin nedarvede, familiært og socialt givne position. Hvor man tidligere - dvs. 'før-moderne' - vandt sin sociale position gennem familie, tradition, kulturel og religiøs placering, er det moderne, rationaliserede samfund kendetegnet ved en principiel udslettelse af enhver sådan traditionsbundet individualitet. Med Webers formulering: "Die Bürokratie ist 'rationalen' Charakters: Regel, Zweck, Mittel, 'Sachliche' Unpersönlichkeit beherrschen ihr Gebaren" (Weber 1976, 578). De moderne samfundsformer indebærer således et umiskendeligt anonymiseringspotentiale, som hænger sammen med deres særlige 'rationelle' og bureaukratiske karakter.

Weber pegede imidlertid ikke blot på rationaliseringen som et uomgængeligt grundtræk ved moderniteten. Som et uadskilleligt følgefænomen så Weber nemlig også, hvad han "ein für allemal" karakteriserede som "Charisma":

'Charisma' soll eine als außeralltäglich ... geltende Qualität einer Persönlichkeit heißen, um derentwillen sie als mit übernatürlichen oder übermenschlichen oder zumindest spezifisch außeralltäglichen, nicht jedem anderen zugänglichen Kräften oder Eigenschaften begabt oder als gottesgesandt ... gewertet wird (Weber 1976, 140).

Mod hverdagens rutineprægede monotoni, mod det anonymiserende bureaukratis dominans i form af individneutrale retningslinjer og ubøjelige paragraffer, står karismaen som det fænomen, der lader en aura af ikke-hverdagsagtig ("Außeralltäglich") fortryllelse skinne over modernitetens affortryllede og betydningsgolde ørken. Karismaen betegner således dét, hvortil der ikke findes regler og abstrakte retningslinjer, og som derfor "nicht nach generellen Normen, weder traditionellen, noch rationalen, sondern ... nach konkreten Offenbarungen und Eingebungen gehandhabt und ist in diesem Sinne 'irrational"' (Weber 1988c, 269). Betyder det, at karismaen skal forstås som et 'irrationelt restprodukt' i en ellers gennemrationaliseret og affortryllet verden? Henholder man sig til Helmuth Spinners udlægning af Webers rationaliseringsteori, er en sådan karakteristik misforstået og udtryk for en trivialisering af Webers modernitetsteori. Karismaen står ikke slet og ret i modsætning til rationaliseringsprocesserne. Snarere udgør den en modernitetskonstitutiv form for komplementært supplement hertil. Forstår man nemlig Webers rationaliseringsteori som en teori om modernitetens dobbelte fornuft ... 
... dann ist nicht nur erklärbar, warum der okzidentalen Rationalisierungsprozeß aus sich heraus Gegentendenzen zunehmender Irrationalisierung erzeugt, sondern auch ausgesprochene Gegenrationalisierungen im Sinne eines Paradigmawechels der Rationalitätsauffassung auslöst (Spinner 1989, 287).

Karismaen skal ikke, som weberreceptionens gængse modstilling lægger op til, forstås som et relikt eller en deficient modus af bureaukratiseringen og rationaliseringen. Derimod skal karismaen tænkes inden for rammerne af rationaliseringen selv. Webers rationaliseringsbegreb skal med andre ord forstås på baggrund af den 'dobbelte bogføring af fornuften', som her er blevet beskrevet og som dermed kan hævdes at være "von epochaler Bedeutung für das (Selbst-)Verständnis der Moderne" (Spinner 1989, 288).

\section{Scientology og rationalisering: to receptionstendenser}

Forsøgene på at begribe Scientology som en specifik moderne religionsform, der artikulerer en række specifikt modernitetsbetingede erfaringer og grundtræk, har været mange. Grundlæggende kan man dog sige, at Scientology tilsyneladende er blevet gjort til genstand for to overordnede receptionstendenser, begge med afsæt i Webers modernitetskonception. Enten har fokus været rettet mod Scientologys slægtskab med den rationaliserings- og videnskabelighedstilvækst, som Webers affortyllelsesmodel har fremhævet ved det moderne (Berger 1974; Wallis 1976; Wilson 1990; Heelas 1996). Eller man har i Scientology set ikke blot religionens genkomst - og dermed et dementi af Webers sekulariseringsteoretiske forestilling om religions endegyldige afvikling som resultatet af moderniseringsprocesser - men også en reaktivering af den karismatiske mystik og fortryllelse, som Weber ligeledes havde teoretiseret (Whitehead 1974; Wallis 1976; Flinn 1983). Lad os derfor i første omgang tage disse to tolkningsveje i nærmere øjesyn.

\section{Scientology som svar på Webers rationaliseringstese?}

Da hovedværket Dianetics. The Modern Science of Mental Health udkom i 1950, var grundstenene til Scientologys tilblivelse samtidig lagt. ${ }^{1}$ I sin oprindelige (dianetiske) konception var Scientology imidlertid slet ikke tænkt som en religion, men derimod som "... the science of mind, of human thought ...", idet den debuterede som "... a totally new science called dianetics ...", som gjorde "precisely what a science of thought should do"), som det begejstret hedder i redaktøren af science fiction tidsskriftet Astounding Science Fiction, John W. Campbells anmeldelse fra 1949 (her efter Wallis 1976, 23). I sin dianetiske kimform står videnskabsprætentionen flere steder så manifest, at der ikke skulle være noget at tage fejl af. Således bærer Dianetik undertitlen 'den moderne videnskab om mental sundhed', ligesom det i forordet bekendtgøres, at

\footnotetext{
${ }^{1}$ Scientologys religiøse formationsperiode kan fastsættes til årene mellem 1952 og 1956. Den første Scientologykirke blev etableret i 1954.
} 
bogen påhviler “... mange års videnskabelig forskning ...” selv om det dog understreges, at forfatteren "... ikke agter at belaste den mindre teknisk orienterede læser med videnskabelig og umulig 'lærd' sprogbrug og grammatik” (Hubbard 1986), hvorved det dog alligevel insinueres, at anliggendet faktisk er af højst videnskabeligt tilsnit.

De utallige referencer til ganske komplekse naturvidenskabelige teorier og indsigter synes i øvrigt at bevidne samme tendens. Termen 'Scientology' er sammensat af det latinske scio - at forstå eller vide og det græske logos - ord, tanke, princip, fornuft (ofte også 'læren om'). Bevægelsen selv oversætter (bl.a.) ordet med "the science of knowing how to know" - altså i relativ intim tilknytning til ordets 'grundbetydning' (ordet findes selvsagt ikke i nogen urform, da det er Hubbards nydannelse på grundlag af græske og latinske elementer). Uomtvisteligt er det imidlertid at ordet, som det umiddelbart står frem, uvilkårligt vækker associationer til videnskab, science. Dette er i sig selv af en vis betydning, da det herved vinder en autoritativ grundklang. I Scientology: The fundamentals of Thought fra 1956 bekendtgøres det med en vis ivrighed, at Scientology er “... en præcis og eksakt videnskab, beregnet på de eksakte videnskabers tidsalder" (Hubbard 1972, 14), og det forklares af den danske udgiver, at L. Ron Hubbard var en amerikansk "videnskabsmand og filosof ... en mand med mange akademiske grader og omfattende studier bag sig" (Hubbard 1972, 17). Det synes allerede på baggrund af disse få tekstuelle stikprøver klart, at Scientology betjener sig af en udtalt videnskabelig selvbeskrivelse. Men det er ikke blot på det eksplicitte, selvbeskrivende niveau, at rekursen til videnskab og rationalitet er iøjnefaldende. Rationalitets- og videnskabsmomenterne har tilsyneladende sat sin tydelige signatur under en betragtelig del af den scientologiske virkelighedsmodel.

Alligevel gør Scientology flere steder fordring på at være selve den omfattende sammenlodning af det videnskabelige og det spirituelle. ${ }^{2}$ Dog er det karakteristisk, at Scientology tillige formulerer sig i direkte opposition til særlige aspekter af Vestens videnskab. Således er det fx bemærkelsesværdigt, at Hubbards egen livshistorie (som indtager en ikke uvæsentlig betydning i Scientologys lære og praksis) rummer et brisant opgør med universitetspsykologien og -psykiatrien.

I bogen What is Scientology? (1978) berettes der fx om Hubbards øjensynlige skuffelser over den vestlige videnskabs impotens for så vidt angår udviklingen af en streng 'videnskab om sindet', hvorfor han snart kom til “... den erkendelse at ingen vidste, hvordan sindet fungerer. Og hvad mere var, ingen inden for områderne psykologi eller psykiatri havde sat sig for at finde ud af det." (her efter Christensen 1997, 27). I en række artikler og essays træder kritikken dog endnu mere i karakter. Her spores psykologiens og psykiatriens syndefald - deres kontroltrang og menneskelige tyranni - tilbage til etableringen af det psykologiske institut i Leipzig i sidste fjerdedel af det 19. årh. Særligt skulle professor Wilhelm Wundts (1832-1920) påstand om, at “der ikke fandtes nogen psyke" (Hubbard 1972, 13) - altså en reduktionistisk og

\footnotetext{
${ }^{2}$ Hvilket skildres billedligt ved den på Dianetikbogens omslag i opaliserende farveprægtighed anførte vulkan: Her sprøjter visdommens scientologiske sæd ud over uvidenhedens sorte søle med naturens uregerlige magt. Scientology fremstår umiskendeligt som visdommens kulminationspunkt.
} 
positivistisk gren af psykologien (behaviorismen) - have fordærvet menneskeheden ganske eftertrykkeligt. Andetsteds fremholder Hubbard med dramatisk anskuelighed konsekvenserne af "... these Leipzig indoctrinated "sychologists"” der lærte mennesket, at det var "a soulless wild animal and presented us on a flaming platter with what is laughingly called modern civilization" (Hubbard 1997, 103). Dramatikken kulminerer dog i følgende passage, hvor Hubbard fastslår, at "on their [these Leipzig indoctrinated 'sychologists'] heels came cultural oblivion and national destruction" (Hubbard 1997, 103). Disse polemiske anslag mod det etablerede psykiatriske (og psykologiske) system, har alle særlige 'antropologiske' grundforestillinger bag sig. Det gale i den akademiskuniversitære psykiatri er således dens materialistiske og objektivistiske menneskeforståelse, der ifølge scientologerne er helt og aldeles forstyrret og som truer med at undergrave hele menneskeheden.

Dette angreb på og opgør med behaviorismen - og bredere betragtet en antropologisk forståelse, der er kalkeret efter en bestemt naturvidenskabelig-'objektivistisk' grundform - lader imidlertid Scientology fremstå i negativets klare silhuet, som kontrasten hertil fremkalder. Scientology forfægter nemlig den præcise modsætning til omtalte antropologiske materialisme. I sin farverige kosmologi (og antropogoni) er et centralt problem således, hvorledes menneskets åndelige kerne - Thetanen ${ }^{3}$ - overhovedet er blevet spærret inde i den fysiske materie (herunder hvordan den vinder udfrielse herfra igen). Hubbard kundgør flere steder, hvorledes 'moderniteten' har forstærket forvanskningen og forkrøblingen af mennesket. I en interessant passage fra 1980, skriver han således, at “ . . old social values have been broken. New moral values have not replaced them ... The ties that held men together as mankind and made them honourable have been sundered by an onslaught of false materialism" (Hubbard 1997, 104). Her identificeres moderniseringen med lanceringen af en 'falsk materialisme', en materialisme som andetsteds ligefrem ansvarliggøres for "brintbombers døvende torden" (Hubbard 1972, 9).

Denne noget ambivalente position mellem på den ene side en eksplicit videnskabelighedsprætention og på den anden side et bredt anlagt videnskabsopgør, synes at løbe som en rød tråd gennem Scientologys selvforståelse. Scientology hævder således på den ene side at stå i modsætning til den moderne, vestlige videnskabstradition, der hævdes at være "... completely divorced from the humanities ..." (Hubbard 1968, 34), på den anden at udgøre selve videnskabelighedens kulminationspunkt.

Generelt benytter Scientology sig af et sprog med en høj grad af teknisk og tilstræbt naturvidenskabelig retorik (fx 'faksimile', 'engram', 'eksteriorisering', 'pre-clear', 'aberration’ og lign.), ligesom kosmologien synes at være konciperet under mærkbar afsmitning fra nyere naturvidenskabelige teoridannelser - fx vækker MEST-begrebet (Mass, Energy, Space og Time) utilsløret associationer i retningen af den moderne relativitetsteori. Herudover står, foruden de associationer som selve navnet giver

\footnotetext{
${ }^{3}$ Afledt af det ottende bogstav i det græske alfabet, $\Theta$, som signalerer 'tanke' eller 'ånd': “Thetanen er personen selv - ikke hans legeme eller navn, ikke det fysiske univers eller hans sind eller noget som helst andet" (Hubbard 1972, 148).
} 
anledning til, den eksplicitte selvprædikation: Scientology som 'sand videnskab', som 'videnskabernes videnskab' og lign. Endelig benytter Scientology sig af et teknisk måleinstrument, E-meteret ('elektropsykometer'), der skal forskaffe scientologen - eller mere præcist auditoren - adgang til lokaliseringen af bestemte hændelser på 'tidssporet' . Retorikken præges altså “... i alt væsentligt af den naturvidenskabelige idéverden, som Hubbard gerne vil definere sig i forhold til” (Christensen 1997, 35).

Bryan Wilson har ligeledes peget på den påfaldende sammenhæng mellem Scientology og modernitetens rationalisering. Det uovertræffelige vidnesbyrd om denne sammenhæng ser Wilson således deri, at "Scientology claims to have ... rationalized the path to salvation" (Wilson 1990, 273). Ifølge Wilson kan Scientology derfor ses som et eksemplarisk udtryk for "the technological age in which it came into existence", idet den er "explicitly committed to the ideal of rational thought", og således generelt repræsenterer "an attempt to discipline, regulate, and routinize access to the supernatural sphere" (Wilson 1990, 274). Som sådan udgør Scientology et forbilledligt eksempel på den weberske affortyllelsestese: Selv religionen er - i den moderne verden - blevet affortryllet og gennemrationaliseret. Eller med Wilsons ord: "Scientology provides technical devices by which to increase the production of salvation: to reduce mystery to salvation" (Wilson 1990, 274).

Det synes med andre ord ubestrideligt, at Scientology i vidt omfang lader en generel appel til videnskab og rationalitet præstere belæg for sine synspunkter, og selve denne “... appeal to the legitimizing force of science ..." (Hammer 2001, 236) afslører tilsyneladende noget karakteristisk ved vor tidsalder.

\section{Scientology som svar på Webers anonymiseringstese?}

Kan Scientology siges at tilbagevise Webers karakteristik af moderniseringens anonymiserende konsekvenser? Umiddelbart kan man hæfte sig ved, at Scientology synes at være konciperet ganske anti-kollektivistisk og generelt synes at opskrive individet. Ikke mindst forekommer det forhold, at scientologen individuelt udvirker sin egen frelse, at efterlade et indtryk af stærk individualisering. Bryan Wilson argumenterer således for, at Scientology kan forstås som udtryk for religiøs privatisering: “... Scientology conforms to the concept of a privatized religion which relies hardly at all on communal expression or community activity" (Wilson 1990, 278). Selv om man naturligvis kan diskutere rimeligheden af denne påstand (jf. Andersen \& Riis 2002), mener jeg, det er rigtigt at hævde, at Scientology lægger markant betoning på den individuelle frelsevej. Forskellige scientologer kan fx befinde sig på vidt forskellige trin på 'Broen til frelse', og kan principielt selv varetage opgraderingen af indsigt. Som sådan minder Scientology om en klassisk gnostisk-esoterisk religion.

Man kunne endvidere hævde, at Scientology - ikke mindst gennem auditeringsprocesserne, der bringer den enkelte scientologs specifikke fortid i tale, og derved aftegner en unik, individuel 'livshistorie' - genererer identitetsfølelse og således lægger den enkeltes personlighed for dagen. Ved at lade individet træde i centrum bryder 
Scientology tilsyneladende med Webers påstand om anonymisering og identitetsløshed som et ufravigeligt udslag af moderniseringen.

Om det betyder, at Haferkamp har ret, når han om Weber kategorisk konkluderer: "Weber hat sich geirrt. Die Entindividualisierungsprognose ist falsch" (Haferkamp 1989, 489), er imidlertid ikke givet. For det synes på den anden side klart, at Scientology - ikke mindst i sin organisatoriske profil - deler udseende med en række store multinationale virksomheder. Som Wallis pointerer: "Scientology is organized on lines similar to those of multi-national enterprises such as the Ford Motor Company, Coca Cola, or International Telephone and Telegraph" (Wallis 1976, 248). Selve Scientologys strukturelle og organisatoriske indretning virker således svært gennemrationaliseret.

Hertil kommer, at en betydelig grad af formalisering og bureaukratisering synes at præge selve auditeringen. Således er auditoren fx forsynet med en særlig 'auditeringsprocedure', som er en generel skabelon for, hvorledes auditoren skal gå frem over for præclear (dvs. den, der bliver auditeret), ligesom der findes en særlig 'auditeringskommunikationscyklus', der nøje angiver den rækkefølge og fremgangsmåde, som auditoren skal henholde sig til i sin kommunikation med præclear. Faktisk er der til hvert trin på Broen et såkaldt 'checksheet', der nøje skal fastslå om retningslinjerne for auditeringen er blevet indfriet. Endvidere forekommer de mange 'niveauer' eller trin på Broen og de dertil hørende specifikke trainee- og auditeringsprogrammer at efterlade et indtryk af bureaukratisk kompleksitet. I særdeleshed må E-meterets mellemkomst mellem auditoren og præclear dog påkalde sig interesse: Her skydes et 'neutraliserende' eller 'objektiverende' måleinstrument ind mellem auditoren og præclear, hvorved enhver personlig fortolkning og potentiel 'farvning' af præclears respons på auditeringen ideelt set suspenderes. E-meteret udvirker således (i scientologernes selvforståelse) en fuldstændig nivellering og formalisering af auditeringsproceduren.

På spørgsmålet om hvorvidt Scientology kan siges at være et svar på Webers anonymiseringstese, må man derfor fastholde, at Scientology på den ene side giver mulighed for at 'italesætte' individualiteten og gøre det personlige til genstand for bevågenhed, ligesom den generelt er orienteret omkring individuel frelse. Som sådan er den udpræget anti-kollektivistisk og dermed alt andet end anonymiserende. På den anden side virker Scientology også (organisatorisk) til at være mærkbart præget af moderne virksomhedsindretning, ligesom de omstændelige, regelbundne procedurer for auditering, E-meterets ideelt set individualitetsneutraliserende funktion og hele frelsevejens bureaukratisk og formelt kodificerede tilsnit efterlader et indtryk af formalistisk bureaukrati og anonymisering. Som sådan svarer Scientology udmærket til de afindividualiserings- og anonymiseringstendenser, som Weber havde annonceret fremkomsten af. Også i denne henseende forekommer Scientology således at være præget af en grundlæggende tvetydighed. 


\section{Scientology og rationalisering: videre perspektiver}

For så vidt som Weber lader sig betragte som en eksponent for en 'traditionel' sekulariseringstanke, synes det oplagt at forstå Scientology og den generelle tilstedeværelse af (ny-)religiøsitet i den moderne verden som et dementi heraf. Religionen er ikke sunket $\mathrm{i}$ jorden i den moderne verden, hvad der ret entydigt synes at afkræfte (en bastant version af) Webers sekulariseringstese. Sagen stiller sig imidlertid mere kompliceret end som så. For som det er blevet godtgjort i det foregående, abonnerer Scientology i mærkbart omfang på en række videnskabs- og rationalitetsprætentioner, der umiddelbart kunne læses i forlængelse af akkurat de rationaliseringsprocesser, som Weber havde identificeret som karakteristiske for det moderne. Som sådan kan Scientology altså ses som en realisering af just de rationaliseringsprocedurer og den videnskabelighedstilvækst, som Weber anså for toneangivende i den moderne vestlige kultur, idet den lægger en udtalt videnskabs- og rationalitetstillid for dagen. Og hvad mere er: Forstår man Webers moderniseringskarakteristik ud fra dennes mere subtile rationaliseringsforståelse, står Scientology ikke blot ikke i modsætning hertil, men forekommer derimod at være et temmelig eksemplarisk udtryk for tilstedeværelsen af den dobbeltfornuft, der er karakteristisk for moderniteten.

\section{Karisma og rationalisering som retoriske midler: Lockes udvej}

I et forsøg på at korrigere det ensidige fokus på Scientologys angivelige indarbejdelse af modernitetsspecifikke rationaliseringstendenser har Harriet Whitehead (1974) fremsat den tanke, at affortryllelsen kun udgør en gren af en mere generel og fundamental moderniseringsproces, der finder sted under stikordene abstraktion og universalisering. Webers begreb om karisma betyder ifølge Whitehead, at mennesket efterlyser "an overarching and universal system of meaning" (Whitehead 1974, 553). Affortryllelsen er således ikke den primære konsekvens af moderniseringen, men derimod kun ét aspekt ved modernitetens mere overordnede projektion af karisma over i videnskaben. Det er således ikke først og fremmest videnskabelig rationalisering, men derimod videnskabens helliggørelse, dens sakralisering, der udgør grundbevægelsen ved moderniseringen. Samme tendens har Frank Flinn tilsyneladende bidt mærke i, når han noterer sig at

From one aspect, Hubbard functions as a 'charismatic leader' and as the original 'researcher'. From another aspect, however, the 'charismatic message' is the technology itself. It is as if technique and routinization were given charismatic authority (Flinn 1983, 104).

Med andre ord er det karakteristiske for moderniteten, her med Simon Lockes gengivelse af Whitehead, at videnskab "becomes ... not a displacement but a distillation out of the charismatic" (Locke 2004, 117). Det er altså selve videnskaben og teknikken, der forsynes med en fernis af karismatisk fortryllelse og autoritet.

Som anført så Weber i karismaens væsen den grundlæggende ambiguitet afspejlet, som karakteriserer modernitetens rationalisering. Det kunne derfor være nærliggende at 
opfatte Hubbard som et eksempel på en karismatisk personlighed, hvis usædvanlige egenskaber og 'magnetiserende' væsen gør, at han netop "als Führer gewertet wird" (Weber 1976, 245). At Hubbard var "a man of powerful personality", hvis "extraordinary character" på et tidspunkt ligefrem blev "transformed into charismatic authority" (Wallis 1976, 248f), lader Wallis ingen tvivl om. Scientology fremstår på denne baggrund som et udtryk for det, som Locke typologisk kalder "the 'charismatic' sense of rationalization" (Locke 2004, 121).

Ifølge Locke beror denne grundlæggende tvetydighed ikke på "the ambuiguity of rationalization" (Locke 2004, 121), men skyldes derimod, at man har misforstået, hvad rationalisering overhovedet er. Locke plæderer således for, at rationalisering ikke skal forstås som en af mennesket uafhængig proces, der dikterer en bestemt virkelighedsforståelse bag om ryggen på mennesket. Derimod er det afgørende at indse, hævder Locke, at rationalisering grundlæggende betegner en diskursiv eller retorisk ressource (Locke 2004, 125). Som sådan er rationaliseringen altså ikke en objektivt virkende, urørlig grundproces bag om moderniteten, men en menneskelig konstruktion, der kan forhandles og ændres i det sociale rum. At der overhovedet består uenighed om, hvad rationalitet og videnskab er, skyldes netop, at disse kategorier først og fremmest er retoriske repræsentationer. At Scientology både kan ses som udtryk for en grundlæggende videnskabelig affortryllelse og som eksempel på karismatisk mystik, viser ifølge Locke

... that 'rationalization' is a matter of human interpretation and representation. As such, it cannot be understood as an external logic that imposes itself upon people, but is a cultural resource over which groups and individuals struggle to achieve and accomplish legitimacy (Locke 2004, 125).

Ved at betragte rationalisering og videnskab som fortolknings- og forhandlingsåbne, retoriske ressourcer, kommer man ifølge Locke ud over den tilbagevendende vanskelighed med at skulle forklare de tilsyneladende modsigelser, der karakteriserer moderniteten. Rationalisering bør ikke forstås 'monolitisk' - hvad enten det er i sin affortryllede 'iron cage'-version eller i sin genfortryllede 'charisma'-version - men skal anskues som forskellige måder, hvorpå “different social contexts” (Locke 2004, 127) konstruerer og legitimerer deres virkelighed.

Der er noget umiddelbart tillokkende ved Lockes socialkonstruktivistiske model. Begreber opfylder ganske rigtigt ikke definitionsentusiasmens præcisionsstandarder og krav om urokkelig entydighed, men er historisk, kulturelt og socialt foranderlige størrelser. Det kan således synes vanskeligt at komme uden om, at mange fænomener unægtelig bærer aftryk af de sociale sammenhænge og 'diskursrum', hvori de optræder og sættes til forhandling. Alligevel er det vel et spørgsmål, om ikke Locke placerer sig i en situation, hvor han fuldstændig afskærer sig fra at kunne skelne mellem videnskabelighed og pseudovidenskabelighed, når han så ensidigt betoner, at rationalisering er en social konstrueret, historisk og perspektivisk variabel overenskomst. I sin iver for ikke at begå afgrænsningens overgreb gør Locke tilsyneladende alle katte grå og lader alt 
være - lige gyldige - menneskeskabte konstruktioner. Men betyder det, at Scientology er videnskab i lige så fuldgyldig forstand som fx den moderne lægevidenskab eller partikelfysik? Det forekommer mig, at Locke tvinges til at smide barnet ud med badevandet, når han lader rationalisering være et spørgsmål udelukkende om sociokulturel konsensus og sproglig konvention.

Hvad enten dette nu er en rimelig indsigelse eller ej: Locke forholder sig udelukkende indirekte til Weber og iscenesætter ham behændigt gennem en konfrontation mellem hhv. Wilson og Whitehead. Dette gør han for mig at se, fordi han har brug for at konstruere sig en problemkulisse, på baggrund af hvilken han kan fremsætte sit eget forførende alternativ. Herved fremstår Lockes socialkonstruktivistiske nødudgang som en attraktiv løsning på det, Locke kalder “Weber's ambiguity” (Locke 2004, 119). Spørgsmålet er imidlertid, om der ikke - i Webers egne ansatser - kan findes en alternativ måde at begribe denne modernitetens ambivalens på.

\section{Kompensationsteoretiske ansatser: Ritterskolen}

Den tyske filosof Joachim Ritter (1903-1974) har i sin tankevækkende Hegelinterpretation (Ritter 2003) udarbejdet en teori om det moderne med udgangspunkt i Hegels begreb om splittelse ('Entzweiung'). Karakteristisk for Ritters modernitetsforståelse er, at det moderne lader sig begribe med udgangspunkt i begrebet om kompensation. Dette i religionsteoretisk øjemed ret udskældte begreb skal imidlertid ikke forstås i traditionel normativt forstand, som det betrængte menneskes virkelighedsflugt gennem uegentlige pseudokompensationer og illusorisk selvbedrag. Derimod er kompensation frem for alt en deskriptiv og modernitetsspecifik beskrivelsesfigur (jf. Marquard 1989). Grundtanken er, at moderniteten viser sig gennem en række splittelser, fx splittelsen mellem naturvidenskaber og åndsvidenskaber, fremtid og fortid, forventning og erfaring osv. Sådanne splittelser er imidlertid kun splittelser i en ren umiddelbar og negativ forstand. Ved nærmere eftersyn konstituerer de nemlig tilsammen hinanden i en enhed, der lader sig begribe med ledetråd i kompensationsbegrebet. Hvad der således hos Hegel fremstilles som en splittelse mellem subjektiv og objektiv ånd eller 'Aufklärung' og 'Aberglaube' (jf. Hegel 1988, 348-84), udvikles af Ritter til generelt at gælde for den moderne verden, idet Ritter - og i forlængelse af ham bl.a. Odo Marquard og Hermann Lübbe - stiller skarpt på en række modernitetskonstitutive kompensationsfænomener. Således opfylder fx æstetikken en for moderniteten grundlæggende og uomgængelig "Kompensationsfunktion" (Marquard 1989, 72), idet den kompenserer for den affortryllelse og det tab af helhedsforståelse, som det moderne, funktionelle og eksakte naturbegreb har foranlediget. Kompensationsbegrebet bliver hermed det begreb, hvormed den dialektiske enhed af tilsyneladende uforenelige modsætninger og modtendenser kan begribes.

Set i lyset heraf kan man tilsvarende sige, at den religiøse kultur ikke overflødiggøres som følge af den stigende rationalisering og affortryllelse, som de moderne naturvidenskaber og oplysningen fører med sig. Tværtimod aktualiserer sådanne affortryllelsesprocesser blot behovet for religionen som det sted, hvor mennesket kan komme 
til rette med de spørgsmål og problemer, hvis uomgængelighed videnskaberne frilægger, ved ikke at udtale sig om.

Som Marquard har bemærket, bliver de moderne, eksperimentelle videnskaber først eksakte gennem en gennemgribende neutralisering af individets unikke livshistorie og tradition, dvs. gennem en bortretouchering af " ... jener lebensweltlichen Traditionen, in denen ihre Wissenschaftler stehen, also durch methodischen Verzicht auf ihre geschichtlichen Herkunftswelten" (Marquard 1986, 104). Tilsvarende er mennesket i den moderne retsstat ikke rettighedssikret, fordi det “... Jude, Katholik, Protestant, Deutscher, Italiener usf. ist" (Hegel 1996, 360), men slet og ret fordi, det er et menneske. På den ene side altså en videnskabelig affortryllelse og individindifferent anonymisering. På den anden side ubehaget herved og de heraf affødte forsøg på at revitalisere den tabte virkelighedsforståelse og redde individuel betydning og identitet fra at forsvinde sporløst $i$ en gennemrationaliseret verden af nøgne sagforhold. Ifølge denne model afstedkommer moderniseringsprocesserne således ikke en fortrængning, men derimod snarere en aktualisering af religiøse tydningsudkast som kompensation for de oplysningsfremskridt, rationalisering og videnskab har ført med sig: "[Die Religion] stirbt durch die erfolgreiche Aufklärung nicht nur nicht ab, sondern ganz im Gegenteil: Je aufgeklärter die moderne Welt wird, desto unentbehrlicher wird die Religion" (Marquard 2000, 123).

Tesen skal her være, at Webers rationaliseringsforståelse med fordel lader sig begribe med udgangspunkt i Hegels dialektiske tænkning (se fx Senigalia 1996) ${ }^{4}$ og det her skitserede kompensationsbegreb. Følgende citat kan tjene som afsæt for en udvikling af denne tese. Weber skriver:

Je mehr der Intellektualismus den Glauben an die Magie zurückdrängt, und so die Vorgänge der Welt 'entzaubert' werden, ihren magischen Sinngehalt verlieren, nur noch 'sind' und 'geschehen', aber nichts mehr 'bedeuten', desto dringlicher erwächst die Forderung an die Welt und 'Lebensführung' je als Ganzes, dass sie bedeutungshaft und 'sinnvoll' geordnet sein (Weber 1976, 308)

Her skriver Weber tilsyneladende under på forestillingen om, at der består et 'dialektisk' forhold mellem på den ene side de oplysnings- og affortryllelsesprocesser, som den rationel-instrumentelle virkelighedsbetragtning fører med sig, og som gør en religiøs tilværelsesforståelse stadig mere uforbindtlig, og på den anden side menneskets stadig mere inciterende krav om, at en sådan religiøs-metafysisk helhedsforståelse ikke desto mindre må være tilgængelig. Det er således hverken kun rationaliserende affortryllelse eller kun karismatisk genfortryllelse, der præger moderniteten, men derimod begge dele som uløselige grundmomenter. Selv om rationaliseringens affortryllelse og den religiøse genfortryllelse på mange måder kan ses som hinandens modsætninger, er det afgørende at bevare blikket for denne ejendommelige dialektik. Det moderne må forstås i sin enhed af tingsliggjort afsakralisering og religiøs genfortryllelse. Det handler med andre

${ }^{4}$ En tilsvarende vurdering findes i Seyfarth 1989, 399. 
ord om at tilbagevinde "die Positivität der Entzweiung als Form der Einheit" (Ritter 2003, 252). Webers opdagelse af modernitetens dobbelte fornuft kan hermed tolkes som et forsøg på at begribe den grundlæggende enhed af tilsyneladende splittelser, som karakteriserer det moderne. Dermed kan kompensationsteorien tjene som en frugtbar fortolkningsnøgle til Webers rationaliserings- og moderniseringsteori. Webers rationaliseringsbegreb kan således, hvis det forstås som et udtryk for den dialektiske enhed af de splittelser i moderniteten, der positivt kan formuleres ved hjælp af kompensationsbegrebet, netop ikke siges at indebære en selvmodsigelse.

\section{Afslutning}

Hermed er det sidste ord om Scientology og modernitetens rationalisering imidlertid næppe sagt. For selv om den fortolkning godtages, ifølge hvilken religion i det moderne udgør et kompensatorisk svar på verdens øgede rationalisering og affortryllelse, synes det trods alt klart, at Scientology er andet og mere end inderliggjorte forsøg på at genfortrylle og revitalisere en affortryllet og betydningstom verden. Den moderne verden er - i al sin uoverskuelige kompleksitet - unægtelig ikke kendetegnet ved, at det religiøse har mistet enhver overbevisningskraft som følge af rationaliseringen. Dette betyder på den anden side ikke, at Webers moderniseringstese uden videre har været et teoretisk blændværk. Rationalisering og affortryllelse udgør indiskutable grundtræk ved moderniteten. Det afslører sig med tankevækkende øjensynlighed derved, at de nyreligiøse bevægelser tager lån i en grundlæggende videnskabslighed (Hammer 1997), der skal forsyne dem med autoritet og troværdighed. Hermed afslører de sig som ægte børn af moderniteten. Den modernitet, frem for alt, som Weber havde annonceret frembruddet af.

\section{Litteratur}

Andersen, Peter Birkelund \& Rie Wellendorf RiIS

2002 "Kilder til et ikke eksisterende fællesskab", Chaos, Dansk-norsk tidsskrift for religionshistoriske studier 37, 9-20.

Berger, PETER

1974 The Homeless Mind. Modernization and Consciousness, Penguin, Hammondsworth.

CHRISTENSEN, DORTE REFSLUND

1997 Scientology. En ny religion, Munksgaard, København.

COLLINS, RANDAL

2000 Max Weber - personen og forfatterskabet, Hans Reitzels Forlag, København.

FLINN, FRANK K.

1983 "Scientology as Technological Buddhism", in: Joseph H. Fichter, ed., Alternatives to American Mainline Churches, Unification Theological Seminary, Barrytown New York, 89-110.

HABERMAS, JÜRGEN

1981 Theorie des kommunikativen Handelns, Suhrkamp Verlag, Frankfurt am Main.

1989 Der philosophische Diskurs der Moderne, Suhrkamp Verlag, Frankfurt am Main. 
HAFERKAMP, HANS

1989 “'Individualismus' und 'Uniformierung' - Über eine Paradoxie in Max Webers Theorie der gesellschaftlichen Entwicklung”, in: Johannes Weiß, ed., Max Weber heute. Erträge und Probleme der Forschung, Suhrkamp Verlag, Frankfurt am Main, 461-96.

HAMMER, OLAV

1997 På jagt efter helheden. New Age - En ny folketro?, Fremad, København.

2001 Claiming Knowledge. Strategies of Epistemology from Theosophy to the New Age, Brill, Leiden.

HeElas, Paul

1996 The New Age Movement. The Celebretation of the Self and the Sacralization of Modernity, Blackwell, Oxford.

HEgEL, GEORG WILHELM FRIEDRICH

1988 Phänomenologie des Geistes, Felix Meiner Verlag, Hamburg.

1996 Grundlinien der Philosophie des Rechts, Suhrkamp Verlag, Frankfurt am Main.

HUBBARD, LAFAYETTE RON

1968 The Phoenix Lectures, The Publications Organization World Wide, Edinburgh.

1972 Scientology. Tankens grundbegreber, New Era Publications, København.

1986 Dianetik. En bog om mental sundhed, New Era Publications, København.

1997 The Humanitarian Freedom Fighter: Articles and Essays, New Era Publications, København.

LOCKE, SIMON

2004 "Charisma and the Iron Cage: Rationalization, Science and Scientology", Social Compass. International Review of Sociology of Religion 51 (1), 111-31.

MARQUARD, ODO

1986 Apologie des Zufälligen, Reclam, Stuttgart.

1989 "Kompensation. Überlegung zu einer Verlaufsfigur geschichtlicher Prozesse", in: Odo Marquard, Ästhetica und Anästhetica. Philosophische Überlegungen, Schöningh, Paderborn, 64-81.

2000 Philosophie des Stattdessen. Studien, Reclam, Stuttgart.

2003 "Positivierte Entzweiung. Joachim Ritters Philosophie der bürgerlichen Welt", in: Joachim Ritter, ed., Metaphysik und Politik. Studien zu Aristoteles und Hegel. Erweiterte Neuausgabe. Mit einem Nachwort von Odo Marquard, Suhrkamp Verlag, Frankfurt am Main, 442-56.

RITTER, JOACHIM

2003 "Hegel und die Französische Revolution", in: Joachim Ritter, Metaphysik und Politik. Studien zu Aristoteles und Hegel. Erweiterte Neuausgabe. Mit einem Nachwort von Odo Marquard, Suhrkamp Verlag, Frankfurt am Main, 183-255.

Senigalia, CRistiana

1996 "Hegel und Weber im Vergleich: Die Bahnen der Rationalität", in: Helmut Schneider, ed., Jahrbuch für Hegelforschung, Academia Verlag, St. Augustin, 86-101.

Seyfarth, CONSTANS

1989 "Über Max Webers Beitrag zur Theorie professionellen beruflichen Handelns, zugleich eine Vorstudie zum Verständnis seiner Soziologie als Praxis", in: Johannes Weiß, ed., Max Weber heute. Erträge und Probleme der Forschung, Suhrkamp Verlag, Frankfurt am Main, 371-405.

SPINNER, HeLmuth F.

1989 “Weber gegen Weber. Der Ganze Rationalismus einer 'Welt von Gegensätzen'. Zur Neuinterpretation des Charisma als Gelegenheitsvernunft", in: Johannes Weiß, ed., Max 
Weber heute. Erträge und Probleme der Forschung, Suhrkamp Verlag, Frankfurt am Main, 250-95.

WALLIS, RoY

1976 The Road to total Freedom. A Sociological Analysis of Scientology, Heinemann Educational Books, London.

WEBER, MAX

1976 Wirtschaft und Gesellschaft. Grundriss der verstehenden Soziologie, Mohr Siebeck, Tübingen.

1988a Die protestantische Ethik und der Geist der Kapitalismus, Gesammelte Aufsätze zur Religionssoziologie I, Mohr Siebeck, Tübingen.

1988 b "Vom inneren Beruf zum Wissenschaft", in: Max Weber, Gesammelte Aufsätze zur Wissenschaftslehre, Mohr Siebeck, Tübingen.

1988c Gesammelte Aufsätze zur Religionssoziologie I, Mohr Siebeck, Tübingen.

WHITEHEAD, HARRIET

1974 "Reasonably Fantastic: Some Perspectives on Scientology, Science Fiction and Occultism", in: I. Zaretsky \& M. Leone, eds., New Religious Movements in Contemporary America, Princeton University Press, Princeton, 547-87.

WILSON, BRYAN

1990 "Scientology: A Secularized Religion", in: Bryan Wilson, The Social Dimensions of Sectarianism: Sects and New Religious Movements in Contemporary Society, Claredon Press, Oxford, 267-88.

Ulrik Houlind Rasmussen

Ekstern lektor, cand.mag.

Institut for Sprog, Litteratur og Kultur

Aarhus Universitet 